\title{
Elisabetta Rasy, Lucien, nostro fratello nella resitenza alla modernità
}

\section{Marco Stupazzoni}

\section{(2) OpenEdition}

1 Journals

\section{Edizione digitale}

URL: https://journals.openedition.org/studifrancesi/39617

DOI: 10.4000/studifrancesi.39617

ISSN: 2421-5856

\section{Editore}

Rosenberg \& Sellier

\section{Edizione cartacea}

Data di pubblicazione: 1 décembre 2004

Paginazione: 393-394

ISSN: 0039-2944

\section{Notizia bibliografica digitale}

Marco Stupazzoni, «Elisabetta Rasy, Lucien, nostro fratello nella resitenza alla modernità», Studi Francesi [Online], 143 (XLVIII | II) | 2004, online dal 30 novembre 2015, consultato il 19 mai 2021. URL: http:// journals.openedition.org/studifrancesi/39617 ; DOI: https://doi.org/10.4000/studifrancesi.39617

Questo documento è stato generato automaticamente il 19 mai 2021.

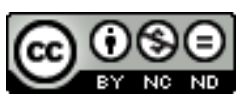

Studi Francesi è distribuita con Licenza Creative Commons Attribuzione - Non commerciale - Non opere derivate 4.0 Internazionale. 


\title{
Elisabetta Rasy, Lucien, nostro fratello nella resitenza alla modernità
}

\author{
Marco Stupazzoni
}

\section{NOTIZIA}

ELISABETTA RASY, Lucien, nostro fratello nella resitenza alla modernità, «Liberal», Anno II, n 10, febbraio-marzo 2002.

1 L'assoluta modernità di Illusions perdues, l'opera capitale dell'intero sistema-Comédie humaine secondo la definizione dello stesso Balzac, si pone ben al di là dell'attualità (drammatica, per certi aspetti) di alcune tematiche sviluppate nel romanzo. Paradossalmente, infatti, l'opera balzachiana è più che nostra contemporanea, poiché essa ci trasmette una lucida e intensa anticipazione dei tempi futuri, cogliendo dell'oggi qualcosa in più di quanto la stessa attualità possa cogliere. È nella figura di Lucien de Rubempré che si concentrano e si realizzano i dissidi e le tensioni più evidenti tra individuo e modernità attraverso le forme della resistenza e della dissimulazione. Lucien diventa il protagonista di una opposizione alla storia che, segnata dai tratti dell'inconsapevolezza, assume non i tratti dell'eroismo, ma quelli, più intimi e nascosti, della mistificazione. 